\title{
Factors Influencing Use of Social Commerce: An Empirical Study from Indonesia
}

\author{
Arief RAHMAN ${ }^{1}$, Refika Nurliani FAUZIA ${ }^{2}$, Sigit PAMUNGKAS ${ }^{3}$
}

Received: September 10, 2020 Revised: November 02, 2020 Accepted: November 16, 2020

\begin{abstract}
This research aims to analyze the factors affecting the acceptance of social commerce, including performance expectancy, effort expectancy, social support, facilitating conditions, hedonic motivation, habitability, price saving orientation, and privacy concerns using the Unified Theory of Acceptance and Use of Technology (UTAUT2). UTAUT2 has been examined and modified in various contexts. The research model studies the acceptance and use of technology in the context of customers. This study adopts a quantitative method using the partial least squares regression (PLS) approach involving 244 respondents. The respondents are users of social commerce in Indonesia. The result of this research indicates that social influence, facilitating conditions, hedonic motivation, habit, price value orientation, and privacy concerns have a significant effect on behavioral intention. On the other hand, performance expectancy and effort expectancy does not affect behavioral intention. Furthermore, price value has a significant effect on social commerce user behavior. Lastly, facilitating conditions and habits does not affect social commerce user behavior. This research contributes to the development of theory by examining an additional variable, which is privacy concern. This study is significant since social media and social commerce have grown exponentially nowadays. Implications of the results for the development of the theory (UTAUT2) and practice are discussed in the article.
\end{abstract}

Keywords: Social Commerce, UTAUT2, Privacy Concern, Indonesia

JEL Classification Code: M15, M40, N35

\section{Introduction}

The number of global Internet users continues to grow and has reached 4.1 billion users by 2019 , reflecting an increase of 5.3 percent compared with 2018 (International Telecommunication Union, 2019). Based on the survey in 2018 by the Indonesian Internet Service Provider Association

${ }^{1}$ FirstAuthor and Corresponding Author. Assistant Professor, Department of Accounting, Faculty of Business and Economics, Universitas Islam Indonesia, Indonesia [Postal Address: Pawirokuat St. No. 1, Condong Catur, Depok, Sleman, DI. Yogyakarta 55283, Indonesia]

Email: arief.rahman@uii.ac.id

${ }^{2}$ Department of Accounting, Faculty of Business and Economics, Universitas Islam Indonesia, Indonesia.

Email: 14312627@students.uii.ac.id

${ }^{3}$ Lecturer, Department of Accounting, Faculty of Business and Economics, Universitas Islam Indonesia, Indonesia.

Email: sigit.pamungkas@uii.ac.id

(c) Copyright: The Author(s)

This is an Open Access article distributed under the terms of the Creative Commons Attribution Non-Commercial License (https://creativecommons.org/licenses/by-nc/4.0/) which permits unrestricted non-commercial use, distribution, and reproduction in any medium, provided the original work is properly cited.
(APJII), Indonesia has also recorded a significant increase of 29 percent, increasing rapidly within two years from 132.7 million in 2016 to 171.2 million Internet users by 2018 . Highlighting the main reasons for Internet usage, the survey results show the need for communication through instant messaging dominates the reasons for Internet usage (24.7 percent), followed by social media usage (18.9 percent). Internet users in Indonesia are actively engaging in social networks such as Facebook (50.7 percent), Instagram (17.8 percent), and YouTube (15.1 percent) (Asosiasi Penyedia Jasa Internet Indonesia, 2019).

Recent web technology brings advanced communication tools to encourage active user interaction and make social media a vast space of global networking. Besides, web technology has sparked the rise of social commerce (s-commerce) as a novel subset of electronic commerce, where social media users act as the main content providers to share experiences and knowledge about a particular product or service (Hajli \& Sims, 2015; Zhang et al., 2014). Social media platforms such as Facebook, Instagram, and YouTube provide features where users can express their reviews of products or services that have been purchased 
through social media networks. Such features enhance user participation and facilitate electronic word-of-mouth (eWOM) communication, social interaction, and social sharing that can affect online sales (Khan, 2017; Phang et al., 2013).

Social commerce is not a new concept in Indonesia and has received much attention and the increasing number of Internet and social media users have made this country a large and promising digital marketplace. Within social commerce, customers not only become passive recipients of information, but also play an active role to share, discuss, endorse, and rate a product based on their experiences (Al-Adwan \& Kokash, 2019; Qalati et al., 2020). Therefore, it is important to understand the key drivers influencing user behavior in the context of social commerce acceptance. Previous studies have demonstrated technology acceptance levels as a key driver to encourage users from different countries such as Saudi Arabia (Sheikh et al., 2017), Lithuania (Gatautis \& Medziausiene, 2014), and Malaysia (Sin et al., 2012) to adopt social commerce. Herrero et al. (2017) examined online privacy issues that affect users when it comes to disclosing their personal information on social networking websites. Wang and Herrando (2019) found that institutional privacy assurance affects users' purchase behavior in social commerce. Fortes \& Rita (2016) analyzed how privacy concerns have an impact on the consumer's intention to make online purchases

This research is aimed to analyze factors affecting social commerce acceptance by referring to the previous studies conducted by Sheikh et al. (2017) and Herrero et al. (2017) and analyzing user behavior in Indonesia. This is because Indonesia is one of the emerging economies with great potential for social commerce growth. Several attempts have been made to leverage social media as a way to encourage business transactions. What has been lacking, however, is an academic effort to shed light on culture's role in influencing consumer's perspectives toward s- commerce ( $\mathrm{Ng}, 2013)$.

\section{Literature Review}

\subsection{Social Commerce (s-commerce)}

The role of social media in today's e-commerce practices is fundamental to create value for customers. Social media is the main platform that provides a broad space for discussion between consumers and brands (company products and services) which impacts the profitability and affects the company's reputation (Tikno, 2017). $\mathrm{S}$-commerce is a rapidly growing platform of e-commerce that utilizes social media and online social interaction to build brand awareness and increase sales. Buying and selling through social media can create a reliable and sustainable platform for buyers and vendors, offering an alternative platform to traditional online approaches. The intention to purchase is the most frequently examined dependent variable and that trust in the s-commerce context is a key factor (Gibreel et al., 2018). S-commerce practice is steered by three major attributes namely, social media technologies, social interactions, and commercial activities, where social media and commercial activities form the basis of s-commerce practices (Liang et al., 2011). S-commerce includes conducting commercial activities at all stages, whether in the need recognition, pre-purchase, purchase, and post-purchase activity, and which is conducted in a social media environment where consumers can connect and interact with others (Ko, 2018).

\subsection{Extended Unified Theory of Acceptance and Use of Technology (UTAUT2)}

Among the analytical models used in many studies to measure individual behavior in adopting technology is the Unified Theory of Acceptance and Use of Technology (UTAUT) model developed by Venkatesh et al. (2003). This model was initially designed based on the organizational contexts to analyze factors that affect employees' intention and actual use of information technology using four direct determinants that affect user acceptance and usage behavior toward information technology adoption, namely performance expectancy, effort expectancy, social influence, and facilitating conditions, and applying four key moderators for those determinants comprising gender, age, experience, and voluntariness of use (EscobarRodríguez \& Carvajal-Trujillo, 2014; Herrero et al., 2017; Macedo, 2017).

Further research conducted by Venkatesh et al. (2012) put an extension to the original UTAUT model by adding three new explanatory variables namely hedonic motivation, price value, and habit. This extended model is known as UTAUT2. Instead of focusing primarily on the organizational contexts, UTAUT2 aims to provide a framework to explain factors, by analyzing multiple constructs at the individual level (see Table 1), which determine user intentions to adopt technologies and the actual use of new technologies. Analytical model using UTAUT2 has been adopted by numerous studies to demonstrate the factors influencing acceptance and use of technology by customers such as in the case of online ticket purchase (Escobar-Rodriguez \& Carvajal-Trujillo, 2014), mobile payment (Morosan \& Defranco, 2016), social networking sites (Herrero et al., 2017), digital divide (Chipeva et al., 2018), and mobile banking (Alalwan et al., 2017). 
Table 1: Definition of Constructs in UTAUT2 mModel.

\begin{tabular}{|l|l|}
\hline Constructs & \multicolumn{1}{|c|}{ Definitions } \\
\hline Performance expectancy & $\begin{array}{l}\text { "The degree to which using a technology will provide benefits to users in performing certain } \\
\text { activities" }\end{array}$ \\
\hline Efforts expectancy & "The degree of ease associated with the use of technology by users" \\
\hline Social influence & $\begin{array}{l}\text { "The extent to which users perceive that "Important others" (e.g., family and friends) } \\
\text { believe they should use a particular technology" }\end{array}$ \\
\hline Facilitating conditions & "Users' perceptions of the resources and support available to perform a behavior" \\
\hline Hedonic motivation & "The fun or pleasure derived from using a technology" \\
\hline Price value & $\begin{array}{l}\text { "Users' cognitive tradeoff between the perceived benefits of the applications and the } \\
\text { monetary cost for using them" }\end{array}$ \\
\hline Habit & "The extent to which people tend to perform behaviors automatically because of learning" \\
\hline
\end{tabular}

Source: (Venkatesh et al., 2012)

\subsection{Privacy Concern}

Privacy concern indicates user responses about possible leaks and potential misuse of personal information (Sun et al., 2019). Every person has a reasonable desire and inherent need to set limits around their personal information to remain private and free from the interference of others (Choi \& Land, 2016; Jeong \& Kim, 2017). In connection with the technology acceptance issue, disclosure of personal information is considered to be a potential cost, and may negatively affect user intention and acceptance in adopting a technology (Fortes \& Rita, 2016). Furthermore, such anxiety may develop system-related privacy concerns as the user may believe that a given technology is not appropriate to protect their privacy (Morosan \& Defranco, 2016). In s-commerce practices, privacy concerns for Internet users can be associated with lower trust and increased risk when they provide personal information for benefits such as free membership. The potential risks that occur can differ from information leaks to attacks on social networks (Kayes \& Iamnitchi, 2017). This study adds privacy concern as an independent variable in the existing UTAUT2 model to measure the intention to adopt technology and actual use of technology at the individual user level.

\subsection{Hypotheses}

UTAUT2 model explains that performance expectancy can affect behavioral intention and the use of technology. When users engage in s-commerce and they get a faster experience and increased productivity in completing an online transaction process, this can increase users' intention to make purchases through s-commerce. Hence, the first hypothesis can be formulated as follows:
H1: Performance expectancy in the use of social media websites for online purchases has a positive effect on online purchase intentions.

Effort expectancy is the convenience level associated with the use of technology which affects the users' adoption behavior. This degree of coziness can be measured when users perceive s-commerce as easy and effortless, thus encouraging higher expectancies to get the desired performance which can influence their behavior in making online purchases through s-commerce. The second hypothesis is formulated as follows:

H2: Effort expectancy in the use of social media websites for online purchases has a positive effect on online purchase intentions.

Social influence deals with the effect of social interactions and relationships such as opinions of friends, family, and other important relatives to persuade and convince users to adopt s-commerce. This means that the influence of the social environment will increase the user's intention to make purchases through social commerce. Facilitating conditions encourage user behavioral intentions and usage behavior. In this context, the support and availability of technological resources (i.e. Internet, mobile phones) to access and practice s-commerce can increase the behavioral intentions and usage behavior in s-commerce. The hypothesis is formulated as follows:

H3: Social influence concerning the use of social media websites for online purchases has a positive effect on online purchase intentions. 
H4: Facilitating conditions concerning the use of social media websites for online purchases has a positive effect on online purchase intentions.

H5: Facilitating conditions concerning the use of social media websites for online purchases has a positive effect on online purchase use

UTAUT2 indicates that hedonic motivation can also determine the behavior intention to adopt a technology. The more users presume that using s-commerce will increase their satisfaction or enjoyment, the higher their intention to purchase in s-commerce. Thus, the next hypothesis is formulated as follows:

H6: Hedonic motivation concerning the use of social media websites for online purchases has a positive effect on online purchase intentions.

Habit indicates how individuals become proficient in using a particular technology because of the repetitive usage in their daily life. UTAUT2 indicates that habit construct has a direct effect on the actual technology usage and adequate influence on user intention. The higher level of habits in using social media will encourage behavioral intention and user intention to adopt s-commerce in making online purchases. Hypotheses are as follows:

H7: Habits concerning the use of social media websites for online purchases have a positive effect on online purchase intentions.

H8: Habits concerning the use of social media websites for online purchases have a positive effect on online purchase use.

The price value in UTAUT2 has been included as a predictor of behavioral intention to use technology. Users will also consider lower prices as a benefit in the use of technology. Therefore, price value represents more perceived value or benefits in adopting the technology. Referring to the previous research conducted by Sheikh et. Al. (2017), price savings (aside from price values as stated in UTAUT2) and perceived benefits were determinants that influence users' behavioral intentions and their intention to adopt social media for online purchases. This paper will adopt price value as a construct to formulate the following hypothesis:

H9: Price value concerning the use of social media websites for online purchases has a positive effect on online purchase intentions.

H10: Price value concerning the use of social media websites for online purchases has a positive effect on online purchase use.

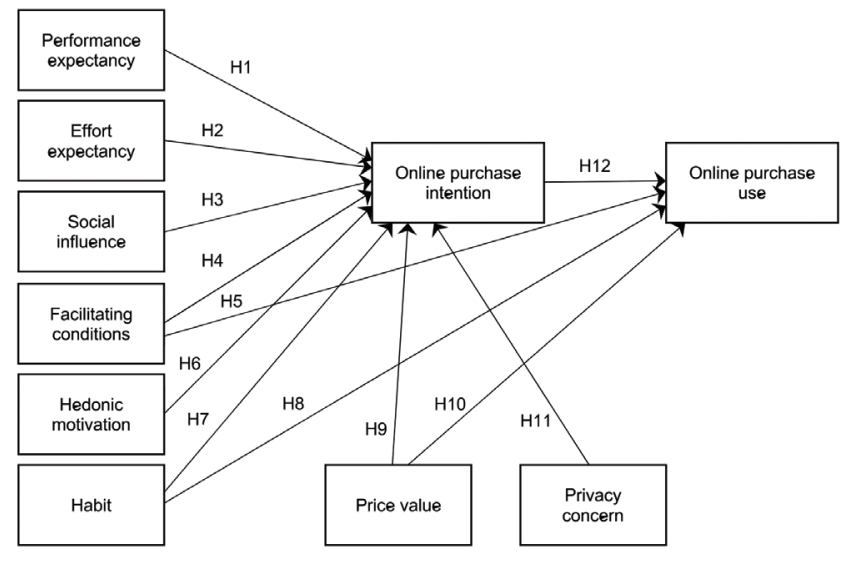

Figure 1: Research Model

Online social networks are built on a foundation of trust where users connect with other users with similar interests or overlapping private trajectories. Therefore, online social networks and related applications can extract an unprecedented amount of personal information giving rise to potential losses caused by disclosing personal information that would raise suspicions and create a negative impact on the use of technology (Kayes \& Iamnitchi, 2017; Morosan \& Defranco, 2016). This paper applies privacy concerns as a construct to examine its influence on online purchase intentions. Finally, UTAUT2 measures that the level of intentions will affect the rate of technology usage. This construct reflects that the higher intentions in the use of s-commerce will affect online purchases made through s-commerce. The research construct of this study is shown in Figure 1.

H11: Privacy concern regarding the use of social media websites for online purchases has a positive effect on online purchase intentions.

H12: Purchase intentions concerning the use of social media websites for online purchases has a positive effect on online purchase use.

\section{Methodology}

\subsection{Population and Sample}

The population of this research is social media users residing in Indonesia. Targeted respondents include active social media users who have at least one social media account (Facebook, Twitter, Instagram, Line, and YouTube), and have made at least one online transaction through s-commerce. Data was collected using a questionnaire (both offline and online) consisting of 49 questions with a 
6-point scale to have respondents give either a positive or negative answer and to avoid indecisive answer choice. The determination of the minimum sample quantity for Structural Equation Modeling (SEM) depends on the highest number of indicators from one variable multiplied by ten (Hair et al., 2011), so the minimum number of samples to be tested in this research is 80 respondents.

In this study, a total of 250 questionnaires were distributed to the target respondents by direct distribution and sharing the hyperlink (via online Google Forms) to complete the survey. Within the data collection period, the returned questionnaires were 247 (98.8\%), including $244(97.6 \%)$ complete responses that could be used for the analysis, and the remaining 3 responses were incomplete.

\subsection{Measurement Development}

Structural equation modeling (SEM) is a technique for measuring causal relationships by using a combination of statistical data and a qualitative causal hypothesis. In particular, this study adopts SEM with a variance-based technique using partial least squares (PLS). PLS is known as a method for constructing predictive models involving various numbers and highly collinear factors, which corresponds to the hypothesized constructs used in this study. PLS can be applied to any data scale and does not require a large sample size (Nguyen, 2020; Pangesti \& Sumertajaya, 2016). PLS-SEM analysis in this research is applied in two stages, including the measurement model (outer model) and the structural model (inner model).

\section{Results}

\subsection{Descriptive Statistics}

Table 2 provides an overview of the respondents' profile involved in this research. Descriptive data presented in the table includes demographic information such as gender, age, educational background, occupation, and income. Based on the sample data collected, the characteristics showed 237 respondents were high school, diploma, and bachelor degree students with an age range between $21-25$ years $(70,5 \%)$ and under 20 years $(10,3 \%)$. Under these conditions, this data sample is considered relevant for testing research instruments because the data sample obtained meets the demographic characteristics of the generation group (Generation Y) that has competent digital literacy (tech-savvy) and has a higher potential to adopt an unfamiliar new technology (Boonsiritomachai \& Pitchayadejanant, 2019; Ng, 2012; Oliveira et al., 2016).

\subsection{Measurement Model}

Convergent validity testing is conducted by measuring the outer loading of the construct indicators to identify the instrument items that can be used as indicators of all latent variables. Under PLS-SEM, the convergent validity testing is measured by the outer loadings $(>0.70)$ and Average Variance Extracted (AVE) to be greater than 0.05. Composite reliability shows the value of the consistency of each indicator in measuring its construct, with a minimum value of 0.70 . The results of the measurement model assessment indicate that the research instrument is valid and reliable (see Table 3).

Table 2: Demographic Characteristics of Respondents

\begin{tabular}{|l|c|c|l|c|c|}
\hline Characteristic & N & $\%$ & \multicolumn{1}{|c|}{ Characteristic } & N & $\%$ \\
\hline Gender & 174 & $71.3 \%$ & High School students & 3 & $1.2 \%$ \\
\hline Female & 70 & $28.7 \%$ & University students & 161 & $66 \%$ \\
\hline Male & & Government officials & 19 & $7.8 \%$ \\
\hline Age & 25 & $10.3 \%$ & SOE employees & 5 & $2 \%$ \\
\hline$\leq 20$ years old & 172 & $70.5 \%$ & Private company employees & 27 & $11.1 \%$ \\
\hline $21-25$ years old & 24 & $9.8 \%$ & Entreprenuers & 15 & $6.1 \%$ \\
\hline $26-30$ years old & 9 & $3.7 \%$ & Others & 14 & $5.7 \%$ \\
\hline $31-35$ years old & 14 & $5.7 \%$ & Income & 95 & $38.9 \%$ \\
\hline$>35$ years old & & <Rp. 1,000,000 & 80 & $32.8 \%$ \\
\hline Education background & 111 & $45.5 \%$ & Rp. 1,000,001-Rp. 2,500,000 & 43 & $17.6 \%$ \\
\hline Senior high school & 51 & $20.9 \%$ & Rp. 2,500,001-Rp. 5,000,000 & 19 & $7.8 \%$ \\
\hline Diploma degree & 75 & $30.7 \%$ & Rp. 5,000,001-Rp. 10,000,000 & 7 & $2.9 \%$ \\
\hline Bachelor/undergraduate degree & 7 & $2.9 \%$ & >Rp. 10,000,001 & & \\
\hline Master degree & & &
\end{tabular}


Table 3: Measurement Model Assessment: Reliability and Convergent Validity

\begin{tabular}{|c|c|c|c|c|c|}
\hline Variable & Item & $\begin{array}{c}\text { Outer } \\
\text { Loadings }\end{array}$ & $\begin{array}{c}\text { Cronbach's } \\
\text { Alpha }\end{array}$ & $\begin{array}{l}\text { Composite } \\
\text { Reliability }\end{array}$ & AVE \\
\hline \multirow[t]{5}{*}{ Online purchase intention } & $\mathrm{Bl} 1$ & 0.788 & \multirow{5}{*}{0.870} & \multirow{5}{*}{0.906} & \multirow{5}{*}{0.660} \\
\hline & $\mathrm{BI} 2$ & 0.870 & & & \\
\hline & $\mathrm{BI} 3$ & 0.792 & & & \\
\hline & $\mathrm{BI} 4$ & 0.734 & & & \\
\hline & $\mathrm{BI} 5$ & 0.870 & & & \\
\hline \multirow[t]{4}{*}{ Effort expectancy } & EE1 & 0.832 & \multirow{4}{*}{0.868} & \multirow{4}{*}{0.910} & \multirow{4}{*}{0.716} \\
\hline & EE2 & 0.806 & & & \\
\hline & EE4 & 0.848 & & & \\
\hline & EE5 & 0.895 & & & \\
\hline \multirow[t]{5}{*}{ Facilitating conditions } & FC1 & 0.876 & \multirow{5}{*}{0.891} & \multirow{5}{*}{0.919} & \multirow{5}{*}{0.696} \\
\hline & FC2 & 0.826 & & & \\
\hline & FC3 & 0.861 & & & \\
\hline & FC4 & 0.786 & & & \\
\hline & FC5 & 0.818 & & & \\
\hline \multirow[t]{4}{*}{ Habit } & HA1 & 0.929 & \multirow{4}{*}{0.924} & \multirow{4}{*}{0.946} & \multirow{4}{*}{0.813} \\
\hline & HA2 & 0.894 & & & \\
\hline & HA3 & 0.893 & & & \\
\hline & HA4 & 0.891 & & & \\
\hline \multirow[t]{3}{*}{ Hedonic motivation } & HM1 & 0.828 & \multirow{3}{*}{0.794} & \multirow{3}{*}{0.878} & \multirow{3}{*}{0.706} \\
\hline & HM2 & 0.838 & & & \\
\hline & HM3 & 0.855 & & & \\
\hline \multirow[t]{3}{*}{ Privacy concern } & PC1 & 0.921 & \multirow{3}{*}{0.904} & \multirow{3}{*}{0.940} & \multirow{3}{*}{0.838} \\
\hline & $\mathrm{PC} 2$ & 0.930 & & & \\
\hline & PC3 & 0.896 & & & \\
\hline \multirow[t]{4}{*}{ Performance expectancy } & PE3 & 0.861 & \multirow{4}{*}{0.891} & \multirow{4}{*}{0.924} & \\
\hline & PE4 & 0.802 & & & 0 $75 ?$ \\
\hline & PE6 & 0.882 & & & 0.152 \\
\hline & PE7 & 0.919 & & & \\
\hline Price value & PSO1 & 0.752 & & & \\
\hline & PSO2 & 0.927 & 0810 & 0 & 0600 \\
\hline & PSO3 & 0.796 & 0.849 & 0.898 & 0.688 \\
\hline & $\mathrm{PSO} 4$ & 0.834 & & & \\
\hline Social influence & SI1 & 0.741 & & & \\
\hline & $\mathrm{SI3}$ & 0.864 & 0910 & 0902 & 0677 \\
\hline & $\mathrm{SI} 14$ & 0.853 & 0.840 & 0.893 & $0.6 / 7$ \\
\hline & SI5 & 0.829 & & & \\
\hline Online purchase use & UB2 & 0.876 & 732 & 0887 & 700 \\
\hline & UB3 & 0.899 & 0.132 & 0.882 & 0.188 \\
\hline
\end{tabular}


Table 4: Results of Hypotheses Testing

\begin{tabular}{|c|c|c|c|c|c|}
\hline \multicolumn{2}{|c|}{ Hypothesis } & \multirow{2}{*}{$\begin{array}{c}\begin{array}{c}\text { Original } \\
\text { Sample }\end{array} \\
0.015\end{array}$} & \multirow{2}{*}{$\begin{array}{c}\begin{array}{c}\mathbf{T} \\
\text { Statistics }\end{array} \\
0.261 \\
\end{array}$} & \multirow{2}{*}{$\begin{array}{c}\text { P Values } \\
0.397 \\
\end{array}$} & \multirow{2}{*}{$\begin{array}{c}\text { Remarks } \\
\text { Not supported }\end{array}$} \\
\hline $\mathrm{H} 1$ & Performance expectancy $\rightarrow$ Online purchase intentions & & & & \\
\hline $\mathrm{H} 2$ & Effort expectancy $\rightarrow$ Online purchase intentions & -0.047 & 0.910 & 0.182 & Not supported \\
\hline $\mathrm{H} 3$ & Social influence $\rightarrow$ Online purchase intentions & 0.166 & 3.578 & $0.000^{*}$ & Supported \\
\hline $\mathrm{H} 4$ & Facilitating conditions $\rightarrow$ Online purchase intentions & 0.145 & 2.337 & $0.010^{*}$ & Supported \\
\hline $\mathrm{H} 5$ & Facilitating conditions $\rightarrow$ Online purchase use & -0.097 & 2.281 & 0.011 & Not supported \\
\hline $\mathrm{H} 6$ & Hedonic motivation $\rightarrow$ Online purchase intentions & 0.125 & 2.136 & $0.017^{*}$ & Supported \\
\hline $\mathrm{H} 7$ & Habit $\rightarrow$ Online purchase intentions & 0.313 & 6.126 & $0.000^{*}$ & Supported \\
\hline $\mathrm{H} 8$ & Habit $\rightarrow$ Online purchase use & 0.020 & 0.434 & 0.332 & Not Supported \\
\hline $\mathrm{H} 9$ & Price value $\rightarrow$ Online purchase intentions & 0.306 & 5.915 & $0.000^{*}$ & Supported \\
\hline $\mathrm{H} 10$ & Price value $\rightarrow$ Online purchase use & 0.092 & 1.473 & $0.071^{* *}$ & Supported \\
\hline $\mathrm{H} 11$ & Privacy concern $\rightarrow$ Online purchase intentions & -0.048 & 1.251 & $0.106^{* * *}$ & Supported \\
\hline $\mathrm{H} 12$ & Online purchase intentions $\rightarrow$ Online purchase use & 0.838 & 13.236 & $0.000^{*}$ & Supported \\
\hline
\end{tabular}

Note: * significance level 5\%; ** significance level: $10 \%$; ${ }^{* * *}$ significance level: $15 \%$

The discriminant validity test is conducted by measuring the AVE root value and cross-loading, where the AVE root value of each variable and the loading value of each indicator must be higher than the cross-loading values. Test results showed that cross-loading values conformed with the requirements $(>0.70)$. The lowest value was found in SI1 (0.611) but this result could be accepted since this result is within the acceptable range of 0.60 to 0.70 (Phuong et al., 2020; Hair et al., 2011; Nguyen, 2020). Based on these results, it can be concluded that the construct has good discriminant validity.

The reliability test aims to determine the degree of accuracy and consistency of the measurement results under the constructs applied in this study. If the value of composite reliability is above 0.70 and Cronbach alpha $(\mathrm{CA})$ is greater than 0.60 , then the construct is considered reliable. Test results showed that all variables used in this study have composite reliability values greater than 0.70 and $\mathrm{CA}>0.60$, meaning that all indicators measured are reliable. As the measurement model results indicate that the reliability, convergent validity, and discriminant validity of the constructs are satisfactory, it can be concluded that the constructs can be used to test the structural model.

\subsection{Structural Model}

The structural model evaluation aims to predict the relation between constructs, significance value, and goodness-of-fit (R-square) of this research model. This test is performed using the SmartPLS 3.0 software application.
In this study, the research model explains $68.9 \%\left(\mathrm{R}^{2}=\right.$ 0.689 ) of the intention to adopt s-commerce for online purchases. Hypotheses related to online purchase intentions, including $\mathrm{H} 3, \mathrm{H} 4, \mathrm{H} 6, \mathrm{H} 7, \mathrm{H} 9$, and $\mathrm{H} 11$ are confirmed, while hypotheses $\mathrm{H} 1$ and $\mathrm{H} 2$ are not confirmed. This model also explains $74.3 \%\left(\mathrm{R}^{2}=0.743\right)$ of variation in online purchase use, and validates the hypothesis related to price savings and perceived benefits (H10), while facilitating conditions (H5) and habit (H8) are not confirmed.

\section{Discussion}

Performance expectancy does not have a significant effect on the online purchase intention using social commerce. This result differs from previous empirical studies confirming this indicator (Macedo, 2017; Morosan \& Defranco, 2016). Nonetheless, these findings are consistent with past researches that concluded performance expectations do not affect consumer intentions in adopting e-commerce ( $\mathrm{Im}$ et al., 2011; Sheikh et al., 2017). Many online businesses in Indonesia are adopting s-commerce to promote their products and services (for example through Instagram and Facebook), but these social media networks are not designed to provide comprehensive features to make it easier for users to make online purchases. Users still have to make transfer payments using ATM, mobile banking, or Internet banking so it takes time and more effort to complete the transaction procedures. Therefore, users may assume that using social media for online purchases does not necessarily complete the process faster. 
129.2 million or 97.4 percent of Internet users in Indonesia are social media users (Asosiasi Penyedia Jasa Internet Indonesia, 2019), making this technology platform no longer a new stage for Indonesian users. Increasing access to social media indicates that this technology adoption experience has become part of the user's day-to-day activities. Therefore, in the context of social media adoption for online purchases, they do not necessarily feel a significant change in their efforts. Based on this research, effort expectancy has no significant effect on the online purchase intention using s-commerce.

Social influence is proven to have a positive influence on online purchase intention using s-commerce. Users find the perceived risk of using technology is reduced when the community and their peers rate a technology positively. This condition encourages general positivity to increase user confidence and certainty to buy a product or service online (Vahdat et al., 2020). Furthermore, social media users tend to rely on available information based on electronic word-of-mouth (eWOM) references from previous users. Despite there is no direct acquaintance, the minimal socialpsychological distance between users and the eWOM issuers will make them sense a closer identity to these people and thereby increasing the likelihood to think of themselves as part of a common social group (Zhao et al., 2020). Given these strong effects, ignoring these social influences would underestimate the potential for shifting user preferences with respect to the use of a technology (Axsen et al., 2013).

In this study, hedonic motivation suggests a positive effect on online purchase intention using s-commerce. Concerning this research context, hedonic motivation is related to the intrinsic motivation that individual users want to achieve to get satisfaction or pleasure which affects the s-commerce technology acceptance and increases online purchase intentions. Business people who use s-commerce must pay attention to the interactions they build through the impression of luxury on their brands. In the context of luxury, hedonic motivation is considered more influential on brand-consumer interactions and purchase intentions than utilitarian motivation (Martin-Consuegra et al., 2019). Therefore, business people must ensure that they provide adequate hedonic value to users in their social media development.

Privacy concerns have a significant negative effect on online purchase intention. This result confirms the findings of previous studies that suggested privacy security considerations which are influenced by situational emotions or individual user concerns when interacting with websites will play a dominant role in driving their interest in making purchases (Li et al., 2011; Mamonov \& Benbunan-Fich, 2017). Users will consider the potential future losses incurred due to disclosure of their personal information so that it affects their beliefs in the safe use of s-commerce technology which affects their interest in making online purchases. However, the negative relationship between privacy concern and online purchase intentions may not necessarily predict the actual user behavior as higher privacy concerns often coincide with better disclosure of information that they can obtain (known as the "privacy paradox") and social networking websites represent prime examples of this phenomenon (Barnes, 2006; Mamonov \& BenbunanFich, 2017). To anticipate such anxiety, s-commerce service providers can offer responsive complaint handling services for their users. Besides, the government needs to implement relevant policy and regulation for s-commerce practice so that users will feel safer to adopt the technology.

\section{Conclusions}

This study revisited the UTAUT2 model proposed by Venkatesh (2012) by adding a privacy concern construct that refers to previous research conducted by Morosan \& Defranco (2016). The limitation of this study lies in the possibility of response bias arising from the diversity of respondents' profiles with different sample sizes wherein their responses do not represent the overall response of a particular group profile or produce the same conclusion for all groups. Future research should consider limiting the sample to a more focused group of respondents, for instance on the group of employees with higher income, taking into account the potential of individuals within this group as active users of social commerce.

This study provides scientific insights to perceive great opportunities to increase the potential use of s-commerce technology, especially for the digital business market in Indonesia. S-commerce service providers need to pay attention to the various key factors that influence the behavior of social media users in Indonesia and use them as an important basis for developing apt strategies to encourage online transactions through s-commerce. The government also needs to play an active role by enacting relevant policies and regulations to encourage the development of the digital ecosystem in the country.

\section{References}

Al-Adwan, A. S., \& Kokash, H. (2019). The driving forces of Facebook social commerce. Journal of Theoretical and Applied Electronic Commerce Research, 14(2), 15-32. https://doi.org/ https://dx.doi.org/10.4067/S0718-18762019000200103

Alalwan, A. A., Dwivedi, Y. K., \& Rana, N. P. (2017). Factors influencing the adoption of mobile banking by Jordanian bank customers: Extending UTAUT2 with trust. International Journal of Information Management, 37(3), 99-110. https:// doi.org/10.1016/j.ijinfomgt.2017.01.002

Asosiasi Penyedia Jasa Internet Indonesia. (2019). Penetration \& profile of behavior of Internet users in Indonesia year 
of 2018. Retrieved from https://apjii.or.id/downfile/file/ SurveiPenggunaanInternetSektorBisnis2013versienglish.pdf

Axsen, J., Orlebar, C., \& Skippon, S. (2013). Social influence and consumer preference formation for pro-environmental technology: The case of a U.K. workplace electric-vehicle study. Ecological Economics, 95, 96-107. https://doi.org/10.1016/j. ecolecon.2013.08.009

Barnes, S. B. (2006). A privacy paradox: Social networking in the United States. First Monday, 11(9), 4-11. https://doi.org/https:// doi.org/10.5210/fm.v11i9.1394

Boonsiritomachai, W., \& Pitchayadejanant, K. (2019). Determinants affecting mobile banking adoption by generation $\mathrm{Y}$ based on the unified theory of acceptance and use of technology model modified by the technology acceptance model concept. Kasetsart Journal of Social Sciences, 40(2), 349-358. https:// doi.org/10.1016/j.kjss.2017.10.005

Chipeva, P., Cruz-Jesus, F., Oliveira, T., \& Irani, Z. (2018). Digital divide at the individual level: Evidence for Eastern and Western European countries. Government Information Quarterly, 35(3), 460-479. https://doi.org/10.1016/j.giq.2018.06.003

Choi, B. C. F., \& Land, L. (2016). The effects of general privacy concerns and transactional privacy concerns on Facebook apps usage. Information and Management, 53(7), 868-877. https:// doi.org/10.1016/j.im.2016.02.003

Escobar-Rodriguez, T., \& Carvajal-Trujillo, E. (2014). Online purchasing tickets for low-cost carriers: An application of the unified theory of acceptance and use of technology (UTAUT) model. Tourism Management, 43, 70-88. https://doi.org/https:// doi.org/10.1016/j.tourman.2014.01.017

Fortes, N., \& Rita, P. (2016). Privacy concerns and online purchasing behavior: Towards an integrated model. European Research on Management and Business Economics, 22(3), 167-176. https:// doi.org/10.1016/j.iedeen.2016.04.002

Gatautis, R., \& Medziausiene, A. (2014). Factors affecting social commerce acceptance in Lithuania. Procedia - Social and Behavioral Sciences, 110(2013), 1235-1242. https://doi. org/10.1016/j.sbspro.2013.12.970

Gibreel, O., AlOtaibi, D. A., \& Altmann, J. (2018). Social commerce development in emerging markets. Electronic Commerce Research and Applications, 27, 152-162. https:// doi.org/10.1016/j.elerap.2017.12.008

Hair, J. F., Ringle, C. M., \& Sarstedt, M. (2011). PLS-SEM: Indeed a silver bullet. Journal of Marketing Theory and Practice, 19(2), 139-152. https://doi.org/10.2753/MTP1069-6679190202

Hajli, N., \& Sims, J. (2015). Social commerce: The transfer of power from sellers to buyers. Technological Forecasting and Social Change, 94, 350-358. https://doi.org/10.1016/j. techfore.2015.01.012

Herrero, A., Martín, S., \& Salmones, M. G. L. (2017). Computers in human behavior explaining the adoption of social network sites for sharing user-generated content : A revision of the UTAUT2. Computers in Human Behavior Journal, 71, 209-217. https:// doi.org/10.1016/j.chb.2017.02.007
Im, I., Hong, S., \& Kang, M. S. (2011). An international comparison of technology adoption. Information \& Management, 48(1), 1-8. https://doi.org/10.1016/j.im.2010.09.001

International Telecommunication Union. (2019). Measuring digital development: Facts and figures 2019. In ITUPublications. https://www.itu.int/en/mediacentre/Documents/ MediaRelations/ITU

Jeong, Y., \& Kim, Y. (2017). Privacy concerns on social networking sites: Interplay among posting types, content, and audiences. Computers in Human Behavior, 69, 302-310. https://doi. org/10.1016/j.chb.2016.12.042

Kayes, I., \& Iamnitchi, A. (2017). Privacy and security in online social networks: A survey. Online Social Networks and Media, 3(4), 1-21. https://doi.org/10.1016/j.osnem.2017.09.001

Khan, M. L. (2017). Social media engagement: What motivates user participation and consumption on YouTube? Computers in Human Behavior, 66, 236-247. https://doi.org/10.1016/j. chb.2016.09.024

Ko, H. C. (2018). Social desire or commercial desire? The factors driving social sharing and shopping intentions on social commerce platforms. Electronic Commerce Research and Applications, 28, 1-15. https://doi.org/10.1016/j. elerap.2017.12.011

Li, H., Sarathy, R., \& Xu, H. (2011). The role of effect and cognition on online consumers' decision to disclose personal information to unfamiliar online vendors. Decision Support Systems, 51(3), 434-445. https://doi.org/10.1016/j.dss.2011.01.017

Liang, T. P., Ho, Y. T., Li, Y. W., \& Turban, E. (2011). What drives social commerce: The role of social support and relationship quality. International Journal of Electronic Commerce, 16(2), 69-90. https://doi.org/10.2753/JEC1086-4415160204

Macedo, I. M. (2017). Predicting the acceptance and use of information and communication technology by older adults: An empirical examination of the revised UTAUT2. Computers in Human Behavior, 75, 935-948. https://doi.org/10.1016/j. chb.2017.06.013

Mamonov, S., \& Benbunan-Fich, R. (2017). Exploring factors affecting social e-commerce service adoption: The case of Facebook gifts. International Journal of Information Management, 37(6), 590-600. https://doi.org/10.1016/j. ijinfomgt.2017.05.005

Martin-Consuegra, D., Diaz, E., Gomez, M., \& Molina, A. (2019). Examining consumer luxury brand-related behavior intentions in a social media context: The moderating role of hedonic and utilitarian motivations. Physiology and Behavior, 200(1), 104110. https://doi.org/10.1016/j.physbeh.2018.03.028

Morosan, C., \& Defranco, A. (2016). It's about time : Revisiting UTAUT2 to examine consumers intentions to use NFC mobile payments in hotels. International Journal of Hospitality Management, 53, 17-29. https://doi.org/10.1016/j. ijhm.2015.11.003

Ng, C. S. P. (2013). Intention to purchase on social commerce websites across cultures: A cross-regional study. Information 
and Management, 50(8), 609-620. https://doi.org/10.1016/j. im.2013.08.002

$\mathrm{Ng}$, W. (2012). Can we teach digital natives digital literacy? Computers and Education, 59(3), 1065-1078. https://doi. org/10.1016/j.compedu.2012.04.016

Nguyen, O. T. (2020). Factors affecting the intention to use digital banking in Vietnam. Journal of Asian Finance, Economics, and Business, 7(3), 303-310. https://doi.org/10.13106/jafeb.2020. vol7.no3.303

Oliveira, T., Thomas, M., Baptista, G., \& Campos, F. (2016). Mobile payment: Understanding the determinants of customer adoption and intention to recommend the technology. Computers in Human Behavior, 61(2016), 404-414. https:// doi.org/10.1016/j.chb.2016.03.030

Pangesti, R., \& Sumertajaya, M. (2016). Partial Least Square Structural Equation Modeling (PLS-SEM) with Biner Data: Case Study on knowledge creation on Dairy Cooperative in Indonesia. Journal, International Engineering, Industrial, 6(4), $327-332$.

Phang, C. W., Zhang, C., \& Sutanto, J. (2013). The influence of user interaction and participation in social media on the consumption intention of niche products. Information and Management, 50(8), 661-672. https://doi.org/10.1016/j. im.2013.07.001

Phuong, N. N. D., Luan, L. T., Dong, V. V., \& Khanh, N. L. N. (2020). Examining customers' continuance intentions towards e-wallet usage: The emergence of mobile payment acceptance in Vietnam. Journal of Asian Finance, Economics, and Business, 7(9), 505-516. https://doi.org/10.13106/jafeb.2020. vol7.no9.505

Qalati, S. A., Li, W., Vela, E. G., Bux, A., Barbosa, B., \& Herzallah, A. M. (2020). Effects of technological, organizational, and environmental factors on social media adoption. Journal of Asian Finance, Economics, and Business, 7(10), 989-998. https://doi.org/10.13106/jafeb.2020.vol7.no10.989

Sheikh, Z., Islam, T., Rana, S., Hameed, Z., \& Saeed, U. (2017). Acceptance of social commerce framework in Saudi Arabia. Telematics and Informatics, 34(8), 1693-1708. https://doi. org/10.1016/j.tele.2017.08.003
Sin, S. S., Nor, K. M., \& Al-Agaga, A. M. (2012). Factors affecting Malaysian young consumers' online purchase intention on social media websites. Procedia - Social and Behavioral Sciences, 40, 326-333. https://doi.org/10.1016/j.sbspro.2012.03.195

Sun, Y., Fang, S., \& Hwang, Y. (2019). Investigating privacy and information disclosure behavior in social electronic commerce. Sustainability (Switzerland), 11(12), 1-10. https:// doi.org/10.3390/su10023311

Tikno, T. (2017). Measuring the performance of Facebook advertising based on media used: A case study on online shops in Indonesia. Procedia Computer Science, 111, 105-112. https://doi.org/10.1016/j.procs.2017.06.016

Vahdat, A., Alizadeh, A., Quach, S., \& Hamelin, N. (2020). Would you like to shop via mobile app technology? The technology acceptance model, social factors, and purchase intention. Australasian Marketing Journal, 40, 1-10. https://doi. org/10.1016/j.ausmj.2020.01.002

Venkatesh, V., Morris, M. G., Davis, G. B., \& Davis, F. D. (2003). User acceptance of information technology: Toward a unified view. MIS Quarterly: Management Information Systems, 27(3), 425-478. https://doi.org/10.2307/30036540

Venkatesh, V., Thong, J. Y. L., \& Xu, X. (2012). Consumer acceptance and use of information technology: Extending the unified theory of acceptance and use of technology. MIS Quarterly: Management Information Systems, 36(1), 157-178. https://doi.org/10.2307/41410412

Wang, Y., \& Herrando, C. (2019). Does privacy assurance on social commerce sites matter to millennials? International Journal of Information Management, 44(2018), 164-177. https://doi. org/10.1016/j.ijinfomgt.2018.10.016

Zhang, H., Lu, Y., Gupta, S., \& Zhao, L. (2014). What motivates customers to participate in social commerce? the impact of technological environments and virtual customer experiences. Information and Management, 51(8), 1017-1030. https://doi. org/10.1016/j.im.2014.07.005

Zhao, Y., Wang, L., Tang, H., \& Zhang, Y. (2020). Electronic word-ofmouth and consumer purchase intentions in social e-commerce. Electronic Commerce Research and Applications, 41(2020), 100980. https://doi.org/10.1016/j.elerap.2020.100980 